2. Герман Л. В., Підгородецька І. Ю., Тихоненко О. В. Основні етапи становлення мовного ландшафту Харкова на тлі соціально-політичних змін. Актуальні питання гуманітарних наук: міжвуз. зб. наук. пр. молодих учених Дрогобицького державного педагогічного університету ім. І. Франка. Дрогобич, 2020. Вип. 28. Т. 1. С. 46-54.

3. Підгородецька І. Ю., Тихоненко О. В. Віконімія Харківщини: номінативний аспект. Мова $i$ культура. 2020. Вип.22. T.V (200). C. $274-282$.

4. Підгородецька І. Ю., Тихоненко О.В.Сакральні назви як компонент онімного простору Харкова: історія і сьогодення. Theoretical and practical aspects of the development of the European Research Area: Monograph / edited by authors. 2nd ed. Riga, Latvia, 2020. P. 303-329.

5. Удовенко Л. О. Урбаноніми антропонімного походження на мапі сучасного Харкова. Вісник Харківського начіонального університету імені В. Н. Каразіна. Сер. «Історія України. Украӥнознавство: історичні та філософські науки». Харків, 2020. Вип. 30. С. 94-107.

DOI https://doi.org/10.30525/978-9934-26-110-7-55

\title{
ЕТНОЛІНГВІСТИЧНІ АСПЕКТИ У ФОРМУВАННІ МОВНОКОМУНІКАТИВНОЇ КОМПЕТЕНЦЇ̈ МАЙБУТНІХ ПЕДАГОГІВ
}

\author{
Стрельбіцька О. О. \\ кандидат філологічних наук, \\ старший викладач кафедри філологіі \\ Комунальний заклад вищої освіти «Луцьький педагогічний коледж» \\ Волинської обласної ради \\ Подолюк С. М. \\ кандидат філологічних наук, \\ викладач-методист кафедри філології \\ Комунальний заклад вищої освіти «Луцький педагогічний коледж» \\ Волинської обласної ради \\ м. Луиьк, Україна
}

Формування національно свідомої, духовно багатої мовної особистості - на сьогодні чи не найважливіше питання національної стратегії розвитку держави загалом, та освітньої реформи зокрема. Аналіз чинних концепцій мовної освіти в Україні свідчить про 
необхідність розробки та впровадження нових ефективних технологій у формуванні етнолінгвістичних, народознавчих компетентностей в сучасної молоді. Значення українознавчої компетенції зумовлене тим, що, послуговуючись українською мовою, особа сприймає, оцінює, створює мовленнєву продукцію, яка стосується різних аспектів минулого, сучасного й майбутнього співжиття соціуму в Україні, а значить, у неї мають бути сформовані українознавчі концепти, які репрезентують національно-мовну картину світу. Варто зауважити, що реалізація такої концепції вимагає насамперед формування сучасного висококваліфікованого комунікативно компетентного педагога-патріота. Саме від того, наскільки професійно учитель володіє словом залежить успіх у навчанні його вихованців, зокрема й розвиток лінгвістичних навичок, які закріплені у всіх видах мовленнєвої діяльності : говорінні, читанні, аудіюванні та писемному мовленні. Відповідно ж, рівень мовленнєвої культури та патріотичної свідомості педагога впливає на становлення духовної культури майбутнього покоління. Таким чином, проблема мовнокомунікативної компетенції все ще залишається важливою в сучасному освітньому та соціокультурному просторі, а іiі актуальність зумовлена новітніми процесами перебудови усіх аспектів $\mathrm{i}$ рівнів спілкування молоді в інформаційному середовищі.

Питання комунікативного підходу формування мовної особистості майбутніх педагогів не перестає бути центром уваги багатьох науковців : педагогів, філологів, культурологів, психологів та інших вчених. Все ж, зазначимо, що чи не найчастіше висвітлювались саме методичні аспекти цієї теми - такі як : мовна компетенція педагогів (М. Муканов, В. Павлов, О. Шахнарович та ін.), мовленнєва компетенція (Г. Богін, Ю. Паскевська, М. Орап, Н. Шацька та ін.), комунікативна компетенція (Т. Гончар, М. Ісаєнко, Т. Кобзар, М. Львов, С. Макаренко, Л. Петровська, О. Попова, Л. Савчук та ін.); технології розвитку комунікативної компетентності вчителя (Г. Андрєєва, О. Бодальов, Ю. Жуков, М. Забродський, В. Кан-Калік, М. Коць, Л. Петровська, Ю. Федоренко та ін.), шляхи та формування мовно/мовленнєвої/комунікативної компетентності у системі освіти (М. Девдера, О. Кучерук, Н. Юрійчук та ін.) [7]. Роль етнопедагогічної основи у навчанні рідної мови неодноразово постає в центрі наукових зацікавлень таких учених, як Н. Бабич, Т. Донченко, С. Срмоленко, В. Кононенко, Л. Мацько, М. Пентилюк, Т. Симоненко, О. Смолінська, М. Стельмахович). Зважаючи, на таку пильну увагу науковців до порушеної проблеми, у своїй розвідці, ми не будемо зосереджуватись на питаннях методики формування зазначених компетенцій у майбутніх педагогів. Натомість, хочемо закцентувати на 
етнолінгвістичних засадах розвитку мовнокомунікативної культури студентів педагогічних закладів вищої освіти, адже саме українознавчий аспект визначається як основний у сучасній концепції вивчення української мови.

Повертаючись до питань наукової дефініції, нагадаємо основні складники професійної компетентності педагога, серед яких вагоме місце належить мовній, мовленнєвій та комунікативній компетенціям. Про тісний взаємозв'язок і тонкі межі між цими поняттями свідчить аналіз статті Н. А. Лопатинської. Дослідниця вважає мовну компетентність передумовою становлення мовленнєвої, яка у свою чергу є підгрунтям формування комунікативної компетенції [7].

Загалом же, до мовної компетенції (як системи знань з граматики, фонетики, лексики, стилістики) належить ряд знань та умінь, формування яких і $є$ метою навчальних занять з лінгвістичних дисциплін. Окрім основних знань з усіх мовознавчих розділів, а відповідно й певних навичок (правописних, орфоепічних, лексичних, граматичних тощо), сюди варто віднести й лінгвосоціокультурні компетенції, тобто знання правил мовленнєвого етикету українців, виразів народної мудрості, етнічної культури).

Мовленнєва ж компетенція, спираючись на мовну, охоплює систему мовленнєвих умінь (уміння вести діалог, сприймати, відтворювати $\mathrm{i}$ створювати усні й писемні монологічні й діалогічні висловлювання різних видів, типів, стилів і жанрів тощо), що необхідно людині для спілкування у різних ситуаціях. Мовленнєва компетентність - одна 3 провідних характеристик особистості, один із найважливіших виявів іiі цілісності й самодостатності.

На основі мовної й мовленнєвої компетенції формується комунікативна, під якою розуміється комплексне застосування мовних $\mathrm{i}$ немовних засобів 3 метою комунікації, спілкування в конкретних ситуаціях.

Проблема формування мовленнєвого розвитку спеціалістів різних професій, а передусім учителів, не втрачає своєї актуальності. Особливо гостро це відчувається в умовах масової діджиталізації освітнього та соціального простору. На сьогодні не достатньо вивчати українську мову просто як систему мовознавчих розділів, а важливо, щоб у молоді формувались глибокі знання історичної основи розвитку рідної мови та завжди виникала гостра потреба у спілкуванні й пізнанні духовного надбання усієї словесної народної культури українців. Відомо, що дослідженням мови крізь призму духовної культури народу займається порівняно нова галузь мовознавства - етнолінгвістика. Відтак, вважаємо, 
що саме етнолінгвістичні аспекти у процесі вивчення рідної мови сприятимуть реалізації українознавчого компоненту державної концепції мовної освіти в Україні [4].

Аналізуючи стан вітчизняної лінгвістичної науки на сучасному етапі, відмітимо, що для мовознавства XXI ст. характерними є напрями, у яких мова розглядається як культурний код нації, а не лише засіб комунікації та пізнання. Відтак, природно, що в Україні в часи активізації національного відродження зростає популярність таких новітніх лінгвістичних напрямів, як соціолінгвістика, медіалінгвістика, лінгвокультурологія та етнолінгвістика, хоча на рівні впровадження в освітній процес ці питання потребують чималої уваги.

Дуже часто мова здається студентам чимось звичним і простим, а насправді цей дивний феномен людини надзвичайно складний і цікавий. Усю глибину пізнання мови і себе, як мовця, як носія величезного багажу духовної спадщини своїх предків дозволяє відчути вивчення такої комплексної та інтегрованої дисципліни як етнолінгвістика. Етнолінгвістика у широкому розумінні охоплює діалектологію (зокрема історичну), історію мови, фольклор, культурну та етнічну історію народу, а також аспекти вивчення мови як соц. явища. У вужчому розумінні це - галузь мовознавства, яка розв'язує проблеми мови і етносу, мови та культури, мови і народної ментальності, мови й міфології тощо [5].

Формування мовнокомунікативних умінь i навичок майбутніх учителів на етнолінгвістичних засадах пов'язане з вивченням мови як оригінального феномена етносу, специфічного способу оцінювання світу, а тому сприяє оволодінню студентами національно-культурним мовним компонентом, поглибленню етнознань та виробленню національного колориту їхнього мовлення. У процесі оволодіння студентами етнічно маркованих ресурсів мови, які відтворюють світоглядні й аксіологічні цінності, формується етнічна ментальність й національна самосвідомість. Ось чому звернення до таких компонентів сприяє духовному зміцненню нації, культурному збагаченню окремої національномовної особистості та забезпечує високий рівень міжетнічної комунікації в Україні [6, с. 7].

Впровадженню етнолінгвістичного напряму у розвиток мовнокомунікативної компетенції майбутніх педагогів, на нашу думку, сприятимуть такі прийоми на заняттях філологічних дисциплін:

- використання під час письмової та усної комунікації текстів українознавчого змісту;

- відтворення національно-культурних текстів 3 подальшим доповненням власними думками; 
- дотримання правил українського комунікативного етикету в різних ситуаціях спілкування;

- грунтовний етнолінгвістичний аналіз художніх текстів;

- написання власних висловлювань (твір-роздум, есе) на українознавчу або етнопедагогічну тематику;

- ведення словників регіональних і соціальних діалектів;

- редагування власних та чужих висловлювань, збагачуючи їх національно орієнтованими мовними одиницями;

- творення популярних медіапродуктів на народознавчу тематику, (ведення етноблогів, створення соціальної реклами 3 популяризацією українознавчого контенту тощо);

- студіювання та створення власних фольклористичних записів 3 рідної місцевості.

Цей список звичайно ж можна продовжувати, відповідно до теми та навчальної дисципліни. До того ж, важливим складником етнолінгвістичного матеріалу $\epsilon$ національно маркована лексика, українські фразеологізми, а також український вітальник, художні й фольклорні тексти, що мають національно-мовну основу [2].

Таким чином, формування у майбутніх педагогів етнолінгвістичної компетентності сприятиме розвитку національно свідомих, духовно багатих носіїв рідної мови серед майбутнього покоління.

\section{Література:}

1. Барилова Г. К., Глуховцева К. Д. (2011). Українська етнолінгвістика. Навчальний посібник. Луганськ: Вид-во ЛНУ імені Тараса Шевченка, 2011. URL: http://dspace.ltsu.org/bitstream/ 123456789/2802/1/Barilova1.pdf

2. Долінська К. Формування етнокомунікативної компетентності студентів у соціокультурному аспекті становлення мовної особистості. Рідне слово в етнокультурному вимірі. 2013. С. 480-484. URL: http://dspu.edu.ua/native_word/wp-content/uploads/2016/04/2013-61

3. Жайворонок В. Українська етнолінгвістика: нариси : навчальний посібник. Київ : Довіра, 2007. С. 67-84.

4. Концепція мовної освіти в Україні. Проект. Освіта України. 2011. С. $1-9$.

5. Хобзей Н. В. Етнолінгвістика. Енциклопедія Сучасної Украӥни: електронна версія [веб-сайт]. Київ: Інститут енциклопедичних досліджень НАН України, 2009. URL: http://esu.com.ua/search_ articles.php?id=18063 (дата звернення: 04.07.2021) 
6. Шарманова, Н. М. (2015). Етнолінгвістика : навчальний посібник для студентів факультету української філології. Кривий Ріг : НПП АСТЕРІКС, 2015. $192 \mathrm{c}$.

7. Lopatynska N.A. Linguistic and communicative competence in university students as a component of future correction teacher. Actual problems of the correctional education: Ministry of Education and Science of Ukraine, National Pedagogical Drahomanov University, Kamyanets-Podilsky Ivan Ohyenko National University. Kamyanets-Podilsky: Medobory2006, 2015.- P. 187-197. URL: https://aqce.com.ua/download/publications/ 203/239.pdf/

DOI https://doi.org/10.30525/978-9934-26-110-7-56

\title{
ІНТЕРПРЕТАЦІЯ МОВНИХ ФОРМУЛ НА ЕТНОКУЛЬТУРНОМУ ТЛІ
}

\author{
Філіпчук М. В. \\ кандидат філологічних наук, \\ доцент кафедри історії та культури украӥнської мови \\ Чернівецький національний університет імені Юрія Федьковича \\ Попович Н. М. \\ кандидат філологічних наук, \\ доиент кафедри історії та культури украӥнської мови \\ Чернівецький національний університет імені Юрія Федьковича \\ м. Чернівиі, Україна
}

Життєдайною силою, невичерпним джерелом мудрості народу є народна мова, народне слово, яке $\epsilon$ засобом пізнання навколишнього світу, історії свого народу, його вірувань та обрядів. Саме у слові, за О. Потебнею, виражається реальна думка, а «сила людської думки не в тому, що слово викликає в свідомості попередні сприйняття, а в тому, як саме воно примушує людину користуватися скарбами свого минулого» [4, с. 143]. Впродовж століття у народній мовній свідомості переосмислюється світ реалій, у результаті чого формується категоризація на модель зовнішнього світу.

Активізація дослідження мовних явищ у світі суміжних галузей знань породили нові наукові напрямки, зокрема й етнолінгвістику. Основу етнолінгвістичних досліджень заклали у своїх працях ще В.фон Гум- 